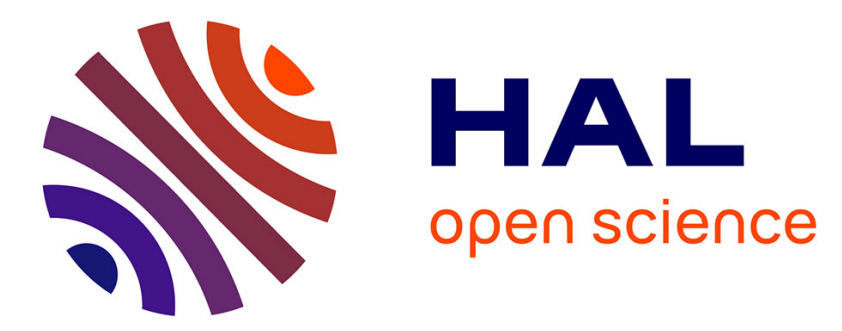

\title{
SODIUM IRON FLUOROPHOSPHITE GLASSES PART II. EPR AND MÖSSBAUER RESONANCE STUDY
}

F. Menil, L. Fournes, J. Dance, J. Videau

\section{- To cite this version:}

F. Menil, L. Fournes, J. Dance, J. Videau. SODIUM IRON FLUOROPHOSPHITE GLASSES PART II. EPR AND MÖSSBAUER RESONANCE STUDY. Journal de Physique Colloques, 1980, 41 (C1), pp.C1-271-C1-271. 10.1051/jphyscol:1980194 • jpa-00219787

\section{HAL Id: jpa-00219787 https://hal.science/jpa-00219787}

Submitted on 1 Jan 1980

HAL is a multi-disciplinary open access archive for the deposit and dissemination of scientific research documents, whether they are published or not. The documents may come from teaching and research institutions in France or abroad, or from public or private research centers.
L'archive ouverte pluridisciplinaire HAL, est destinée au dépôt et à la diffusion de documents scientifiques de niveau recherche, publiés ou non, émanant des établissements d'enseignement et de recherche français ou étrangers, des laboratoires publics ou privés. 


\section{SODIUM IRON FLUOROPHOSPHITE GLASSES PART II, EPR AND MÖSSBAUER RESONANCE STUDY}

F. Menil, L. Fournes, J.M. Dance and J.J. Videau

Laboratoire de Chimie du Solide du C.II.R.S., 33405 TaZence-Cedex, France.

Abstract - EPR and Mössbauer measurements have been performed on sodium iron fluorophosphate gilasses. Mössbauer spectra show the presence of $\mathrm{Fe}^{3+}$ and $\mathrm{Fe}^{2+}$ both in octahedral coordination sites. However, for low iron concentration, EPR suggests a small number of $\mathrm{Fe}^{3+}$ tetrahedra coexisting with $\mathrm{Fe}^{3+}$ octahedra. On the basis of these results, $\mathrm{Fe}^{3+}$ tetrahedrally and/or octahedrally coordinated, connected with $\mathrm{P}(\mathrm{O}, \mathrm{F})_{4}$ tetrahedra would behave as a network-former cation, whereas $\mathrm{Fe}^{2+}$ would substitute for $\mathrm{Na}^{+}$as a network-modifier. Long range magnetic order previously observed by magnetic measurements has been confirmed for iron-rich compositions.

Submitted to : Journal of Non-Crystalline Solids. 